\title{
CHESTNUT-COLLARED LONGSPURS NEST NEAR MORDEN, MANITOBA
}

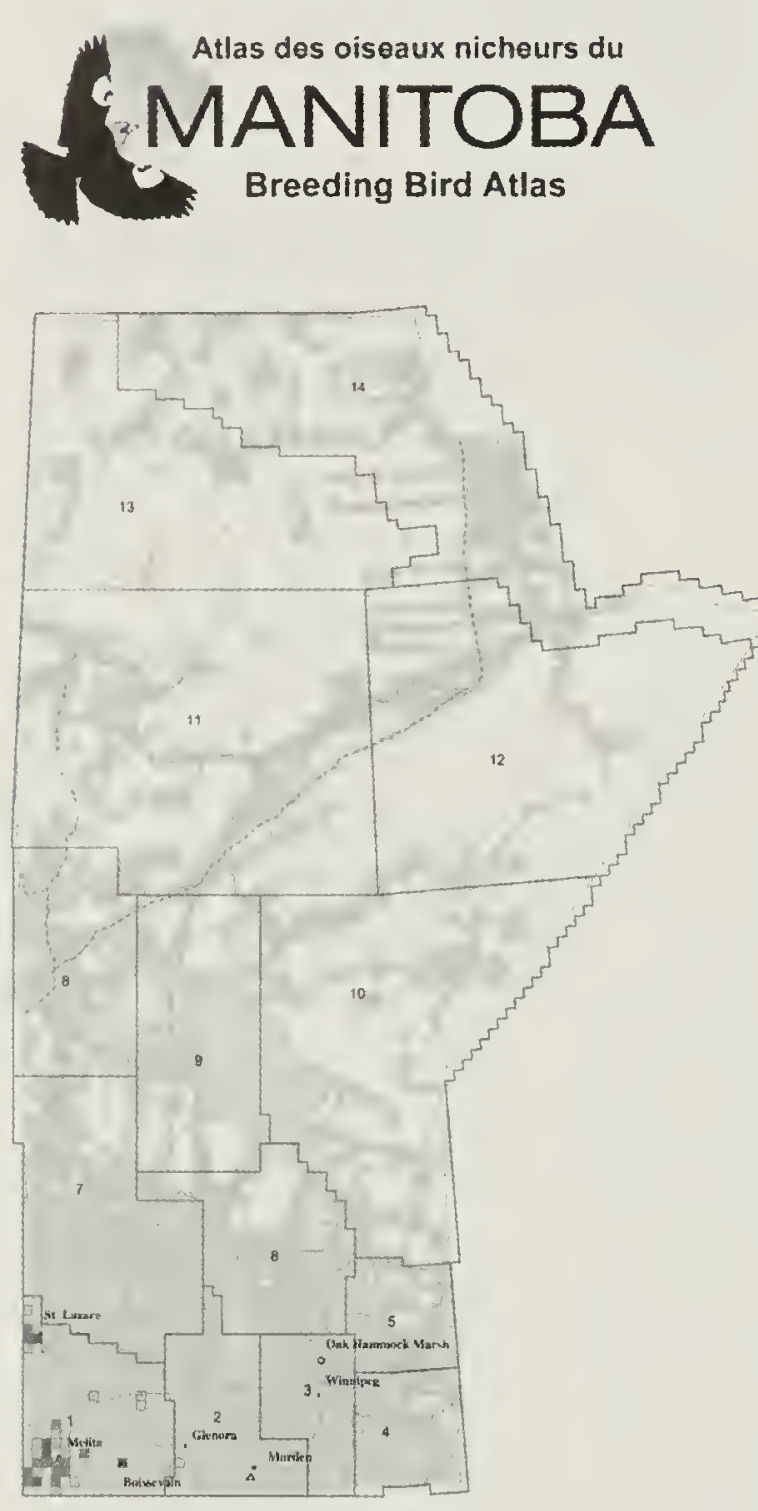

Chestnut-collared Longspur Bruant à ventre noir Calcorras ornatus

\section{Breeding Evidence Nidification \\ Possible \\ Probable \\ Confirmed / Confirmée Not Surveyed / Pas recensé \\ Not Observed / Pas observé}
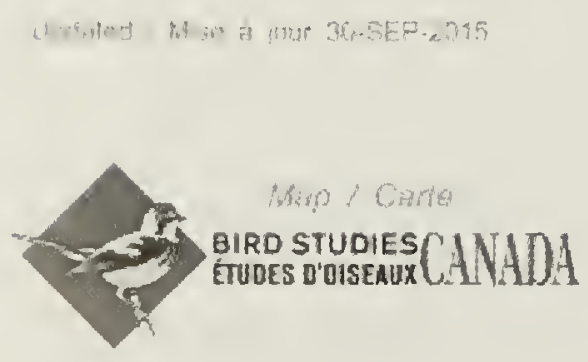

Breeding evidence map of the chestnutlongspur during the Manitoba Breeding (2010-2014).8 The triangle marks the ting location near Morden, Manitoba.

\section{J. Paul Goossen \\ 2-18 Fairway Dr. \\ Morden, MB R6M 0B2 \\ pgoossen@mymts.net}

\section{Henry Nikkel}

105-1 Rampton St.

Morden, MB R6M 1W6

hennik@mymts.net

The chestnut-collared longspur (Calcarius ornatus) breeds in North America's Northern Great Plains. ${ }^{1}$

In Canada, this iconic grassland species is found in mixed-grass and short-grass prairies and plains from Manitoba to Alberta. ${ }^{2,3}$

The chestnut-collared longspur reaches the northeastern edge of its North American distribution in Manitoba where in the late 1800s it was considered to be common in suitable habitat. ${ }^{4}$ Although it nested as far north and east as Winnipeg, East Shoal Lake and the Oak Hammock Marsh area until at least the mid-1990s, the chestnutcollared longspur's breeding range in Manitoba is now limited to the southwest corner of the province where it is considered to be locally fairly common (R. Koes, pers. comm.). ${ }^{5,6,7}$

Participants of the Manitoba Breeding Bird Atlas (MBBA) project (2010-2014) verified the provincial breeding range of the chestnutcollared longspur, confirming that the longspur's breeding range is indeed restricted to southwestern Manitoba, primarily near Melita and St. Lazare (Fig. 1). ${ }^{8}$ In this note, we document the nesting of chestnut-collared longspurs outside of their current breeding range in Manitoba but within their historical breeding range.

On June 20, 2015, the authors encountered two chestnut-collared longspurs in a pasture ( 9 ha), 6.4 km south-southwest of Morden. The pasture (Fig. 2) contained a relatively large lowland area that could seasonally retain water. J.P. Goossen and V. Goossen visited the pasture later that day and confirmed the presence of two males and one female. On June 21, 2015, H. Nikkel returned to the pasture and observed a male and female chestnut-collared longspur in the same area and suspected there might be a nest as the female was observed flying over and then dropping into the grass and remaining there for about 10 to 15 minutes. One or both members of the pair were again observed by $\mathrm{H}$. Nikkel on June 25, 28 and 29. On July 4 , J.P. Goosen visited the pasture and observed a female and male, both with food in their beaks, dropping into the grass at different times, a short distance from the fence line A second pair was seen 90 m east of the first pair also flying down into the grass just north of the fence line. Nesting was not observed.

On July 7, H. Nikkel located and photographed the nest of the first pair in a tuft of grass about $7 \mathrm{~m}$ from the pasture fence and about $14 \mathrm{~m}$ from the road. He did not approach the nest too closely to check its contents; however, four nestlings were seen in one of the photographs (Fig. 3) he took during the visit. We assume the nest contained longspur chicks but we can not rule out the possibility that the nest may have had at least one brown-headed cowbird (Molothrus ater) chick. During this visit, both male (Fig. 4) and female were again observed carrying food; the female was observed with food at the nest. H. Nikkel observed the male on July 12 and both adults on July 17. J.P. Goossen visited the pasture on July 24 but did not locate any longspurs.

The chestnut-collared longspur nest was located in the Rural 


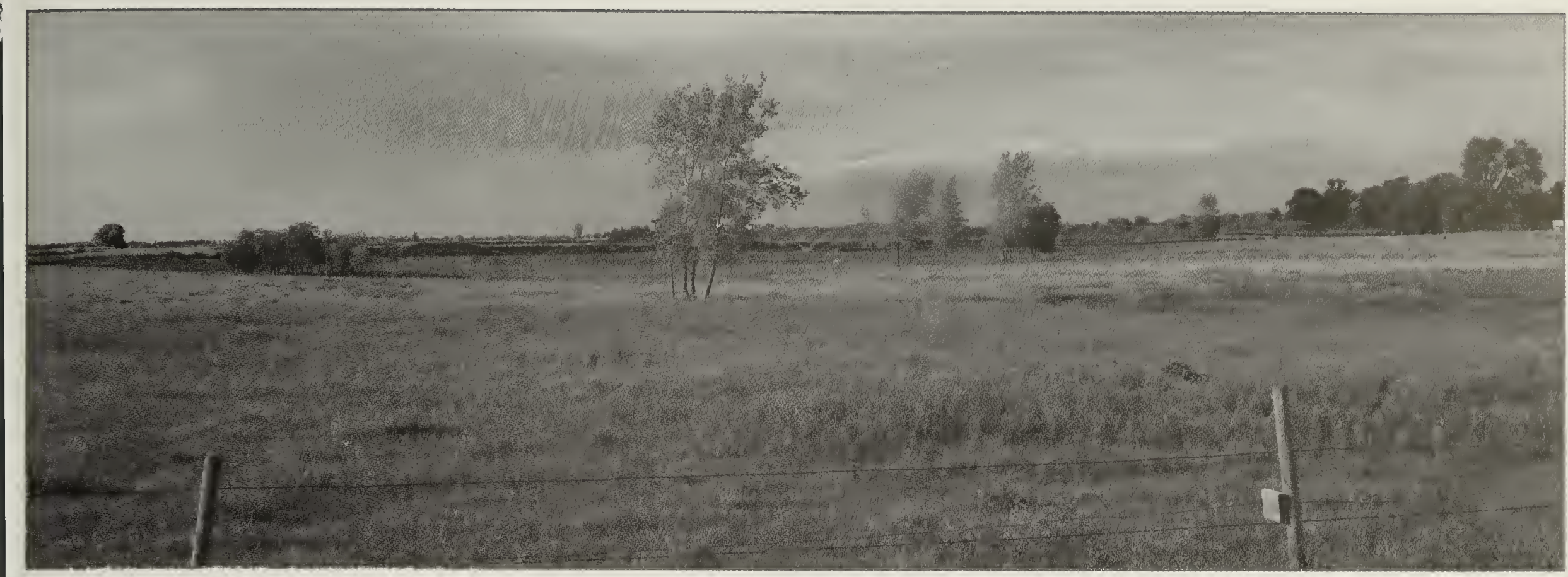

Figure 2. Chestnut-collared longspur habitat near Morden, Manitoba. Photo credit: Paul Goossen

Municipality of Stanley (RMS) in south-central Manitoba about 110 $\mathrm{km}$ southwest of Winnipeg. During the recent $M B B A$, the closest sighting of a chestnut-collared longspur to the Morden site was about $80 \mathrm{~km}$ west-northwest near Glenora, and the nearest confirmed breeding location was about $140 \mathrm{~km}$ west, near Boissevain. ${ }^{8}$ The primary current breeding range of the longspur in Manitoba is about $215 \mathrm{~km}$ west of the Morden site. Although chestnutcollared longspurs are widespread in neighbouring North Dakota, their presence in that state's Northeastern Drift Plain, southwest of Morden, is considered to be uncommon ${ }^{9}$ The closest North Dakota breeding location to the nest reported in this note was in Towner County, about $85 \mathrm{~km}$ to the southwest ${ }^{9}$ Chestnutcollared longspurs are also known to have nested as far east as western Minnesota. ${ }^{10}$

Chestnut-collared longspurs have previously been recorded in the RMS. On April 26, 1981, J.P. Goossen observed a male singing and giving a flight display $13 \mathrm{~km}$ southeast of Morden in about 16 ha of grassland habitat. On June 15, 1986, J.P. Goossen observed a chestnutcollared longspur about $2 \mathrm{~km}$ west of Morden in grassland habitat. He recorded it as "probable" as he did not have binoculars to confirm the sighting, but given it was a sparrowsized bird with extensive white on its tail and a reddish-brown neck, it no doubt was that species. On June 12,1990 , he observed a male and female chestnut-collared longspur in the same grassland (old pasture) as the bird seen in 1986. He also observed a male carrying out an aerial flight song over a pasture on June 13, 1990, about $3 \mathrm{~km}$ southwest of Morden. Other observers have noted this species in the RMS as well. From 1989 through 1994, chestnut-collared longspurs were observed each April in pastures about $6 \mathrm{~km}$ south-southwest of Morden. Numbers ranged from two to six individuals (R. Koes, pers. comm.). To our knowledge, the observations in this note of chestnutcollared longspurs in the RMS are the first since 1994.

The chestnut-collared longspur is considered to be a rare visitor or migrant outside of its core breeding range in southwestern Manitoba? The nesting of chestnut-collared longspurs near Morden, however, extends its current known breeding range into south-central Manitoba. Historically south-central Manitoba no doubt was part of the longspur's regular breeding range. Prior to settlement, native grassland was extensive in southern Manitoba. The grazing of bison (Bison bison) and effects of prairie fires would have modified the height of grasslands and thereby provided suitable nesting habitat for chestnut-collared longspurs. ${ }^{11}$ In 1806, Alexander Henry, while viewing the Red River plains from the Pembina Escarpment near the current town of Morden, recalled that he had "many times beheld these plains covered with buffalo at all seasons of the year"..$^{12}$ In time the bison disappeared from southern Manitoba and settlers arrived, many of whom would have grazed their cattle and horses on the native grasslands, also creating habitat suitable for chestnut-collared longspurs.

Grasslands in the Northern Great Plains have declined significantly with the advance of settlement and agriculture. ${ }^{9,13}$ Loss of chestnutcollared longspur breeding habitat has also been noted in Manitoba. 6,14 Breeding Bird Survey data show that the chestnut-collared longspur population is in a long-term decline within its North American range, as well as in Manitoba. ${ }^{15}$ The primary factors affecting its population decline appear to be fragmentation and loss of habitat. ${ }^{3}$ Both population decline and habitat loss contributed to the decision to list the species as Threatened in Canada. ${ }^{3,16}$ In Manitoba, the chestnut-collared longspur is listed as Endangered. ${ }^{17}$

Grassland pasture is under continued threat in south-central 


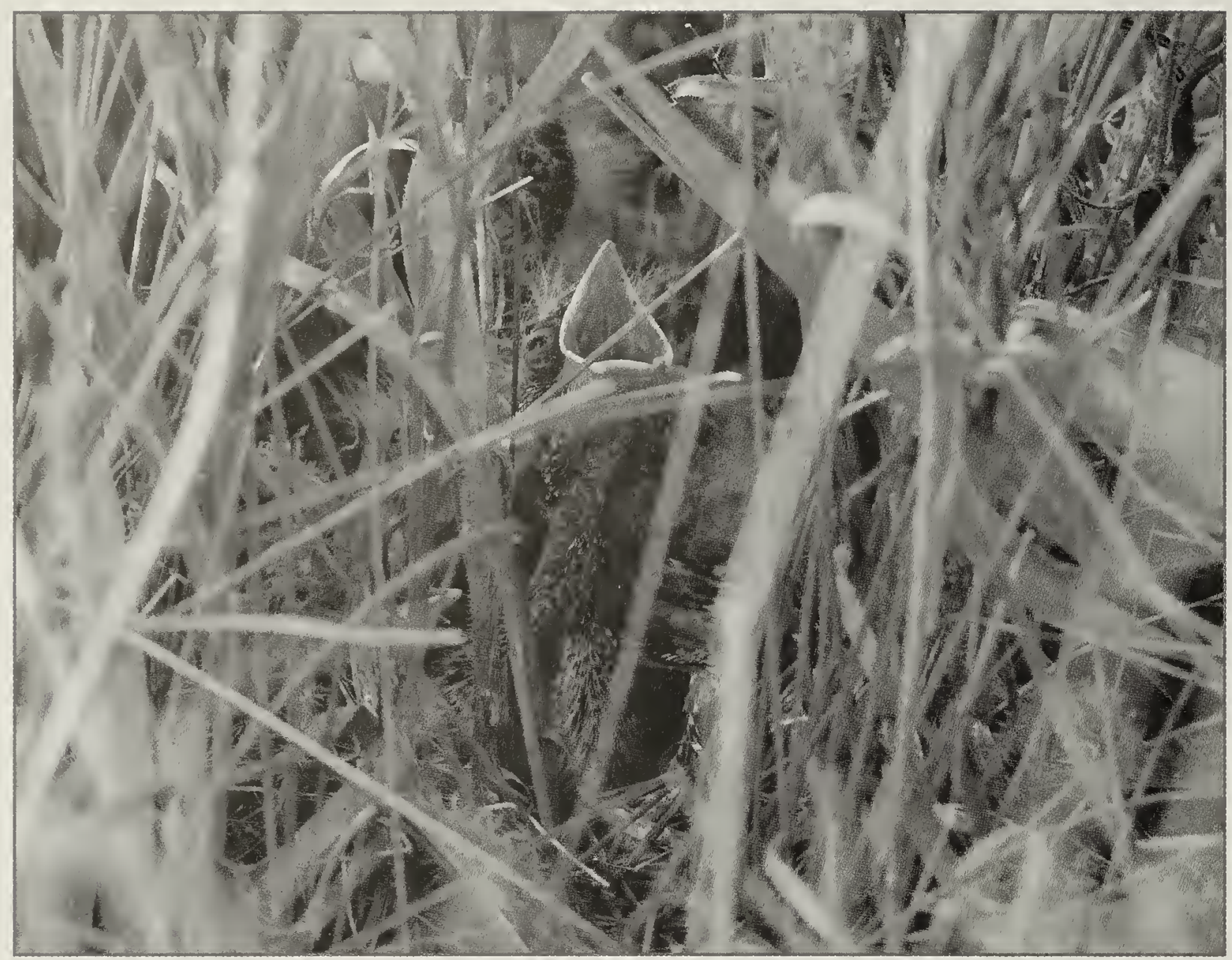

Figure 3. Chestnut-collared longspur nest with young near Morden, Manitoba. Photo credit: Henry Nikkel

Manitoba. The initial breaking of native grasslands in southern Manitoba in the 1800s and continued expansion of agriculture has resulted in significant loss of Manitoba's tall and mixed-grass prairies. ${ }^{13}$ Urbanization, acreage development and resource extraction are all factors that threaten grassland habitats in the RMS. Grassland pastures, though not extensive in the RMS, are the most likely habitat that could support breeding pairs of chestnutcollared longspurs. Grazing is critical to creating suitable nesting habitat for longspurs in Manitoba as this province's higher annual precipitation promotes greater grass growth than experienced in arid regions of Saskatchewan and Alberta. ${ }^{18}$ Conserving and maintaining grassland habitats in the RMS is important not only for species at risk like the chestnut-collared longspur, but also for other obligate grassland species.

\section{Acknowledgements}

We thank C. Artuso, V. Goossen and R. Koes for their comments on the manuscript. We also thank K. Ellison, D. Hill and S.G. Sealy for their assessment on the identity of the photographed nestlings. Retrieved from http://sararegistry.gc.ca/
8. Manitoba Breeding Bird Atlas (2015) Breeding evidence map for Chestnutcollared Longspur. Retrieved from www. birdatlas.mb.ca.

9. Stewart RE (1975) Breeding Birds of North Dakota. Tri-College Center for Environmental Studies, Fargo, ND.

10. Green JC, Janssen RB (1975) Minnesota Birds: Where, When and How Many. University of Minnesota Press, Minneapolis, MN.

11. Bleho B, Ellison K, Hill DP and Gould LK (2015) Chestnut-collared Longspur (Calcarius ornatus). In: Poole A (ed) The Birds of North America Online. Ithaca: Cornell Lab of Ornithology, NY. Retrieved from the Birds of North America Online: http://bna. birds. cornell.edu/bna/ species/288.

12. Henry A, Thompson D and Coues $E$ (1965) New Light on the Early History of The Greater Northwest. The Manuscript Journals of Alexander Henry Fur Trader of the Northwest Company and of David Thompson Official Geographer and Explorer of the Same Company 1799 1814; Exploration and Adventure among the Indians on the Red, Saskatchewan, Missouri, and Columbia Rivers. Vol. 1. Ross and Haines Inc. Minneapolis, MN.

2. Godfrey WE (1986) The Birds of Canada (Revised Edition). National Museums of Canada. Ottawa

3. COSEWIC (2009) COSEWIC assessment and status report on the Chestnutcollared Longspur (Ca/carius ornatus) in Canada. Committee on the Status of Endangered Wildlife in Canada. Ottawa. virtual_sara/files/cosewic/sr_Chestnutcollared\%20Longspur_0810_e1.pdf.

4. Thompson EE (1891) The Birds of Manitoba. Proceedings of the United States National Museum Vol. 13: 457 643

5. Harris RD (1944) The Chestnut-collared Longspur in Manitoba. Wilson Bulletin 56:105-115.

6. Gardner, KA (1981) Birds of Oak Hammock Marsh Wildlife Management Area. Manitoba Department of Natural Resources, Winnipeg, MB.

7. Holland GE, Curtis CE, Taylor P (2003) Chestnut-collared Longspur. In: Manitoba Avian Research Committee The Birds of Manitoba. Manitoba Naturalist Society, Winnipeg, Manitoba. p. 367.
13. Samson F, Knopf F (1994) Prairie Conservation in North America. Bioscience 44:418-421.

14. Knapton RW (1979) Birds of the Gainsborough - Lyleton Region. Special Publication No. 10, Saskatchewan Natural History Society, Regina, SK

15. Sauer JR, Hines JE, Fallon JE, Pardieck KL, Ziolkowski Jr. DJ, Link WA (2014) The North American Breeding Bird Survey, results and analysis 1966 - 2013. Version 01.30.2015 USGS Patuxent Wildlife Research Center, Laurel, MD. Retrieved from www.mbr-pwrc.usgs.gov/bbs/bbs. html.

16. Government of Canada (2015) Species at Risk Public Registry. Retrieved from wnw. registrelep-sararegistry.gc.ca/default. asp?lang $=E n \& n=24 F 7211 \mathrm{~B}-1$.

17. Manitoba Conservation and Water Stewardship (2015) Species at Risk. Retrieved from www.gov.mb.cal conservation/wildlife/sar/sarlist.html.

18. Environment Canada (2015) Canadian Climate Normals. Retrieved from http:// climate.weather.gc.ca/climate_normals/. 


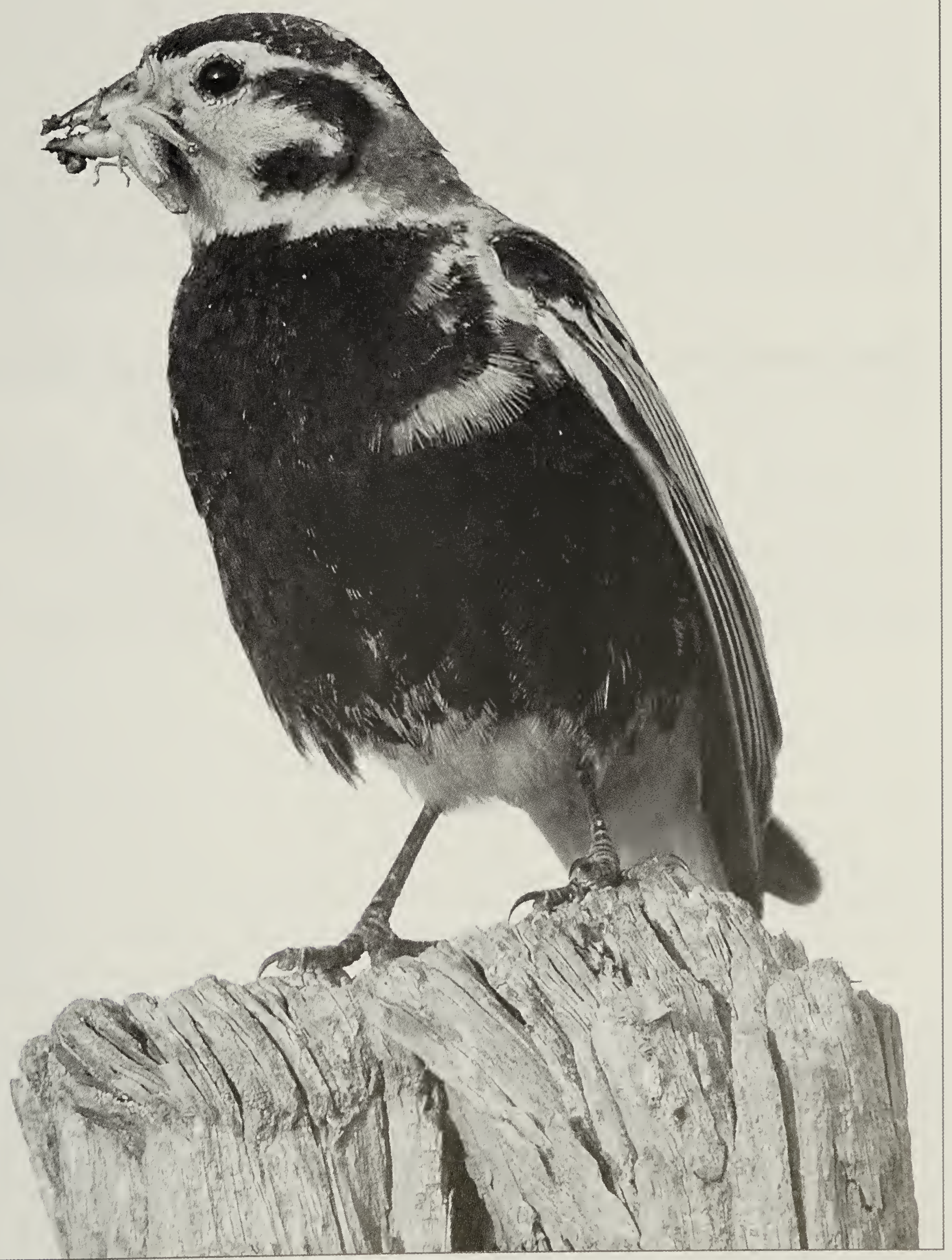

Figure 4. Adult male chestnut-collared longspur with food near Morden, Manitoba. Photo credit: Henry Nikkel 